УДК: 657

Голячук Н.В., к.е.н, доцент

Голячук С.Є., к.с.-Г.н, доцент

Луцький національний технічний університет

\title{
АНАЛІЗ ЛІКВІДНОСТІ ТА ФІНАНСОВОЇ СТІЙКОСТІ ЛІСОГОСПОДАРСЬКИХ ПІДПРИЕМСТВ ВОЛИНСЬКОЇ ОБЛАСТІ
}

Наведено методику аналізу коефіцієнтів ліквідності та фінансової стійкості підприємства на основі форми 1 «Баланс», подано їх коротку характеристику та нормативні значення. Розраховано показники ліквідності та фінансової стійкості лісогосподарських підприємств Волинської області.

Ключові слова: фінансовий стан підприємства, лісогосподарське підприємства, коефіцієнти ліквідності, коефіцієнти фінансової стійкості.

Holyachuk N., Holyachuk S.

\section{ANALYSIS OF LIQUIDITY AND FINANCIAL SUSTAINABILITY OF FORESTRY ENTERPRISES OF THE VOLYN REGION}

The method of analysis of liquidity and financial stability coefficients of the enterprise on the basis of Form 1 "Balance" is given, their brief description and normative values are given. The indicators of liquidity and financial stability of forest enterprises of the Volyn region are calculated.

Key words: financial state of the enterprise, forest enterprise, liquidity coefficients, coefficients of financial stability.

Голячук Н.В., Голячук С.Е.

\section{АНАЛИЗ ЛИКВИДНОСТИ И ФИНАНСОВОЙ УСТОЙЧИВОСТИ ЛЕСОХОЗЯЙСТВЕННЫХ ПРЕДПРИЯТИЙ ВОЛЫНСКОЙ ОБЛАСТИ}

Приведена методика анализа коэффициентов ликвидности и финансовой устойчивости предприятия на основе формы 1 «Баланс», представлены их краткие характеристики и нормативные значения. Рассчитаны показатели ликвидности и финансовой устойчивости лесохозяйственных предприятий Волынской области.

Ключевые слова: финансовое состояние предприятия, лесохозяйственное предприятия, коэффициенты ликвидности, коэффициенты финансовой устойчивости.

Постановка проблеми у загальному вигляді i iї зв'язок 3 важливими науковими та практичними завданнями. Волинь належить до багатої на ліси території України. Лісогосподарську діяльність на Волині здійснюють: Волинське обласне управління лісового та мисливського господарства (Волинське ОУЛМГ) до складу якого входять 26 підприємств: лісогосподарських, спеціалізованих, мисливських (90,4\%) та інші користувачі $(9,6 \%)[1]$.

Пріоритетними напрямками розвитку лісової галузі Волині $\epsilon$ насамперед проведення лісовідновлення, охорона та захист лісу, проведення рубок, пов'язаних 3 веденням лісового господарства, рубок головного користування, збереження та відтворення мисливської фауни, переробка деревини.

Діяльність лісогосподарського підприємства в значній мірі залежить від здатності зібрати і проаналізувати потрібну інформацію, а також від своєчасності прийняття управлінських рішень. Тому важливого значення набуває здійснення фінансового 
аналізу роботи кожного підприємства лісового господарства. Для дослідження фінансового стану візьмемо 12 саме лісогосподарських підприємств і проаналізуємо показники їх ліквідності та фінансової стійкості. Для проведення аналізу використана фінансова звітність лісогосподарських підприємств за 2014-2017 роки [2].

Аналіз останніх досліджень, у яких започатковано вирішення проблеми.

Вагомий внесок в розробку теоретичних та методологічних аспектів аналізу фінансового стану підприємств в цілому, та аналізу ліквідності і фінансової стійкості підприємств, зокрема, внесли відомі науковці: Г.В. Савицька, Г.Г. Кірейцев, Чумаченко, А.Д. Шеремет, С.В. Мних.

Цілі статті. Дослідити практичні аспекти аналізу ліквідності та фінансової стійкості лісогосподарських підприємств Волинської обл. та сформулювати висновки.

Виклад основного матеріалу дослідження 3 повним обгрунтуванням отриманих наукових результатів. Функціонуючи в ринковій економіці як суб'єкт підприємницької діяльності, кожне підприємство має забезпечувати такий стан своїх фінансових ресурсів, за якого воно стабільно зберігало б здатність безперебійно виконувати свої фінансові зобов'язання перед своїми діловими партнерами, державою, власниками, найманими працівниками. Набуваючи в ринкових умовах не уявної, а справжньої фінансової незалежності, несучи реальну економічну відповідальність за ефективність господарювання i за своєчасне виконання фінансових зобов'язань, підприємства здатні досягти стабільності своїх фінансів лише при суворому додержанні принципів комерційного розрахунку, головним серед яких $\epsilon$ зіставлення витрат i результатів, одержання максимального прибутку за мінімальних витрат. Саме ця умова $\epsilon$ визначальною для формування фінансового стану підприємства [3].

Фінансовий стан підприємства - забезпеченість підприємства необхідними фінансовими ресурсами і ступінь раціональності їх розміщення для здійснення ефективної господарської діяльності та своєчасного проведення грошових розрахунків за своїми зобов'язаннями. Фінансовий стан підприємств можна оцінити 3 погляду його короткострокової та довгострокової перспектив. Критерієм оцінки фінансового стану підприємства $€$ його ліквідність і платоспроможність, тобто здатність своєчасно і в повному обсязі розрахуватися за короткостроковими зобов'язаннями.

Коефіцієнт загальної ліквідності (К п) дає загальну оцінку платоспроможності підприємства та показує, скільки гривень поточних активів підприємства припадає на одну гривню поточних зобов'язань.

$$
K_{n}=\frac{\phi .1 p .1195}{\phi .1 p .1695}
$$

Якщо поточні активи підприємства перевищують його поточні зобов'язання, то підприємство є ліквідним. Якщо $K_{\text {п }}<1$ то це низька ліквідність, якщо $1<K_{\Pi}<2$, то це ознака нормальної ліквідності, коли цей показник вище 2 - це висока ліквідність.

Визначимо коефіцієнт загальної ліквідності для лісгоспів Волинської області (рис.1). В 2014 році більшість лісогосподарських підприємств мали низький коефіцієнт загальної ліквідності. Три підприємства Ковельське ЛГ, Любешіське та Маневицьке ЛГ мали нормальну ліквідність, оскільки їх показники були більше 1. 


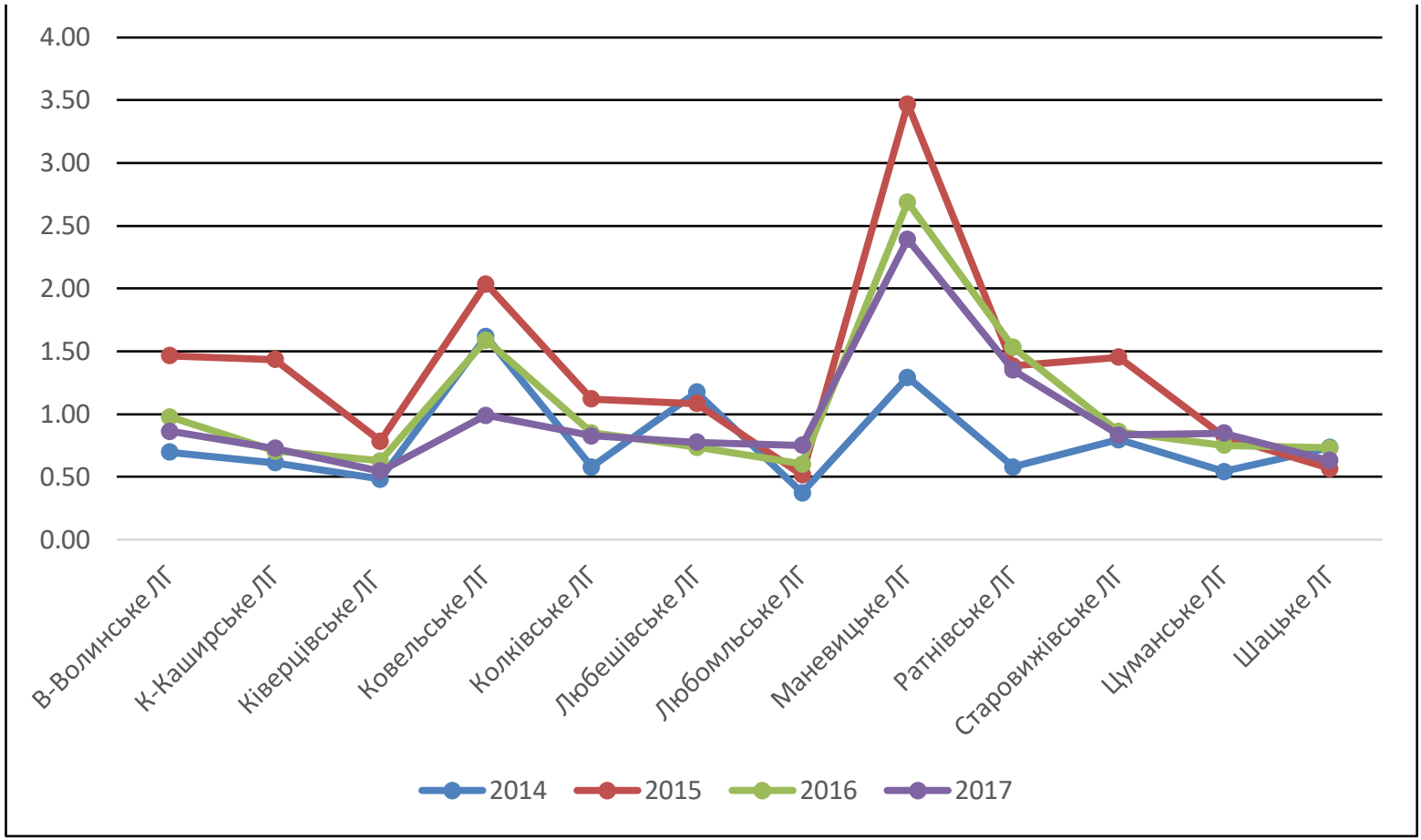

Рис. 1. Коефіцієнт загальної ліквідності лісогосподарських підприємств Волинського ОУЛМГ

Джерело: власні розрахунки

В 2015 році коефіцієнт загальної ліквідності мав нормативне значення уже в п'яти державних лісогосподарських підприємства, що свідчило, що підприємства можуть розрахуватися зі своїми боргами. А два підприємства Маневицьке ЛГ та КовельськеЛГ перевищили нормативний показник 2 та мали високу ліквідність. Показник загальної ліквідності Маневицького ЛГ становив 3,47, а це означало, що на 1 грн. поточних зобов'язань підприємства в 2015 році припадало 3,47 грн. активів підприємства.

В 2016 році всі досліджувані підприємства погіршили показники загальної ліквідності в порівнянні з попереднім роком, але при цьому Маневицьке ЛГ мало високу ліквідність - 2,69.

В 2017 році показники загальної ліквідності лісогосподарських підприємств впали до низького рівня. I лише ліквідність Ратнівського ЛГ була нормальною з показником 1,35, та Маневицького ЛГ - високою, з показником 2,39.

Такі зміни показників загальної ліквідності підприємств лісогосподарського комплексу викликані як зростанням оборотних активів так і значним ростом поточних зобов'язань.

Далі проаналізуємо коефіцієнт поточної ліквідності.

Коефіцієнт поточної (швидкої) ліквідності враховує якість активів і є точнішим показником ліквідності, оскільки для його розрахунку враховуються найбільш ліквідні поточні активи (запаси не враховуються) [13].

$$
K_{\text {uл }}=\frac{\phi .1 p \cdot(1125+1135+1130+1145+1155+1160+1165+1190)}{\phi .1 p .1695} ;
$$

Цей показник показує платіжні можливості підприємства щодо погашення поточних зобов'язань за умови своєчасного здійснення розрахунків 3 дебіторами. Теоретично значення коефіцієнта вважається достатнім, якщо воно перевищує 0,6.

Розраховані показники коефіцієнта поточної ліквідності подані на рис. 2. 
В 2014 році тільки три підприємства: Ковельське ЛГ, Любешівське ЛГ та Маневицьке ЛГ мало достатне значення коефіцієнта поточної ліквідності. В 2015 році фінансовий стан підприємств показав, що вже 7 лісгоспів мали нормативне значення показника швидкої ліквідності.

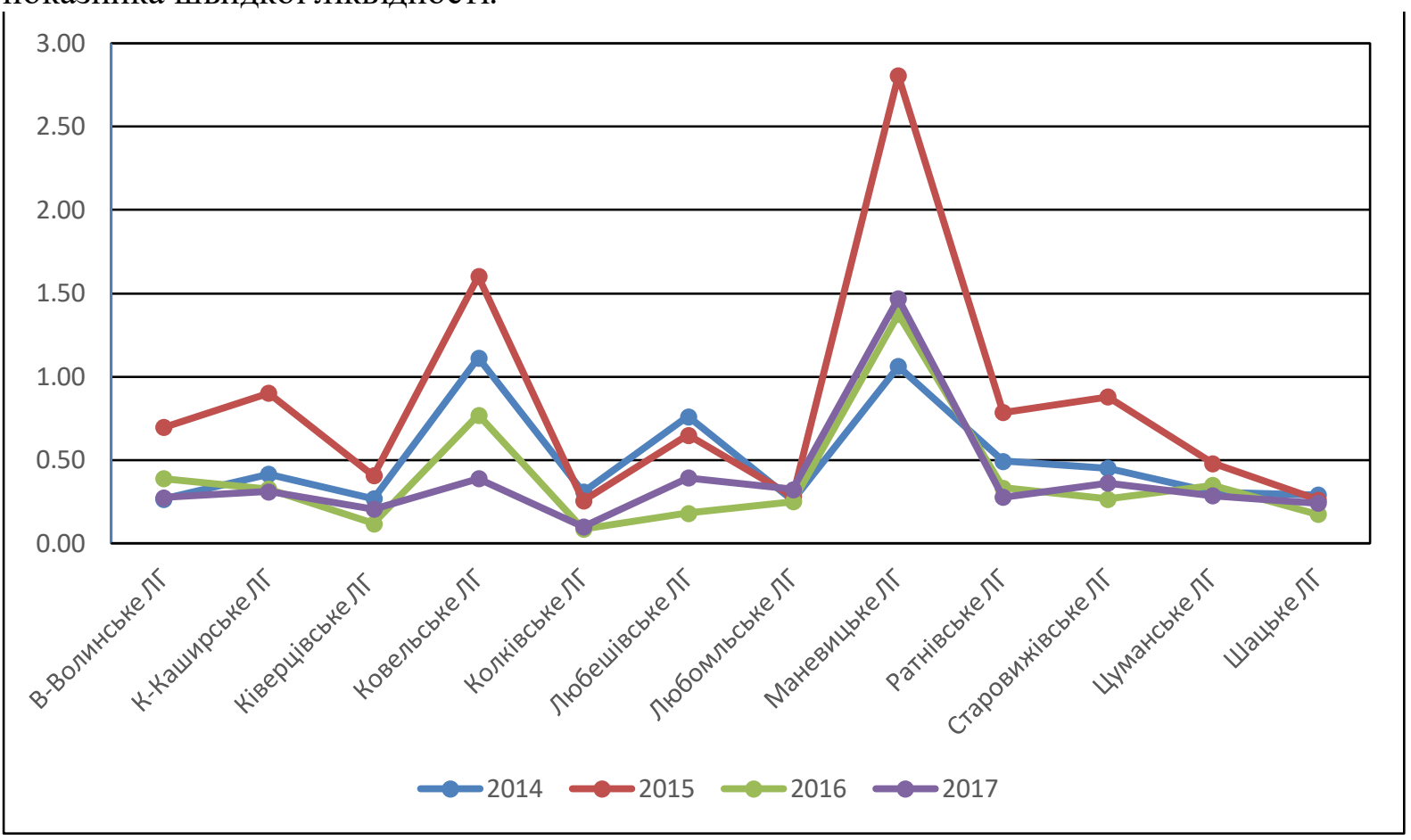

Рис. 2. Коефіцієнт поточної (швидкої) ліквідності лісогосподарських підприємств Волинського ОУЛМГ

Джерело: власні розрахунки

3 діаграми бачимо, що за 2016 та 2017 роки майже всі лісогосподарські підприємства погіршили свої показники в порівнянні з 2015 роком. Тільки в двох підприємствах в 2016 році: Ковельському ЛГ та Маневицькому ЛГ коефіцієнт поточної ліквідності був більшим 0,6. В 2017 році тільки Маневицьке ЛГ мало можливість своєчасно погасити свої борги по зобов'язаннях, оскільки коефіцієнт поточної ліквідності становив 1,47 .

Переходимо до аналізу коефіцієнта абсолютної ліквідності.

Коефіцієнт абсолютної ліквідності (Кал $)$ характеризує ту частину короткострокової заборгованості, яку підприємство має можливість погасити негайно.

$$
K_{a л}=\frac{\phi .1 p \cdot(1160+1165)}{\phi .1 p .1695}
$$

Теоретично значення коефіцієнта вважається достатнім, якщо воно перевищує $0,2 \ldots 0,3$. На практиці ж значення бувають значно нижчі, і за цим показником не можна відразу робити негативні висновки про можливості підприємства негайно погасити свої борги, тому що малоймовірно, щоб всі кредитори підприємства одночасно пред'явили б йому свої вимоги. У той же час, занадто високе значення показника абсолютної ліквідності свідчить про нераціональне використання фінансових ресурсів.

Розглянемо динаміку коефіцієнта абсолютної ліквідності на лісогосподарських підприємствах Волинської обл. (рис. 3) 


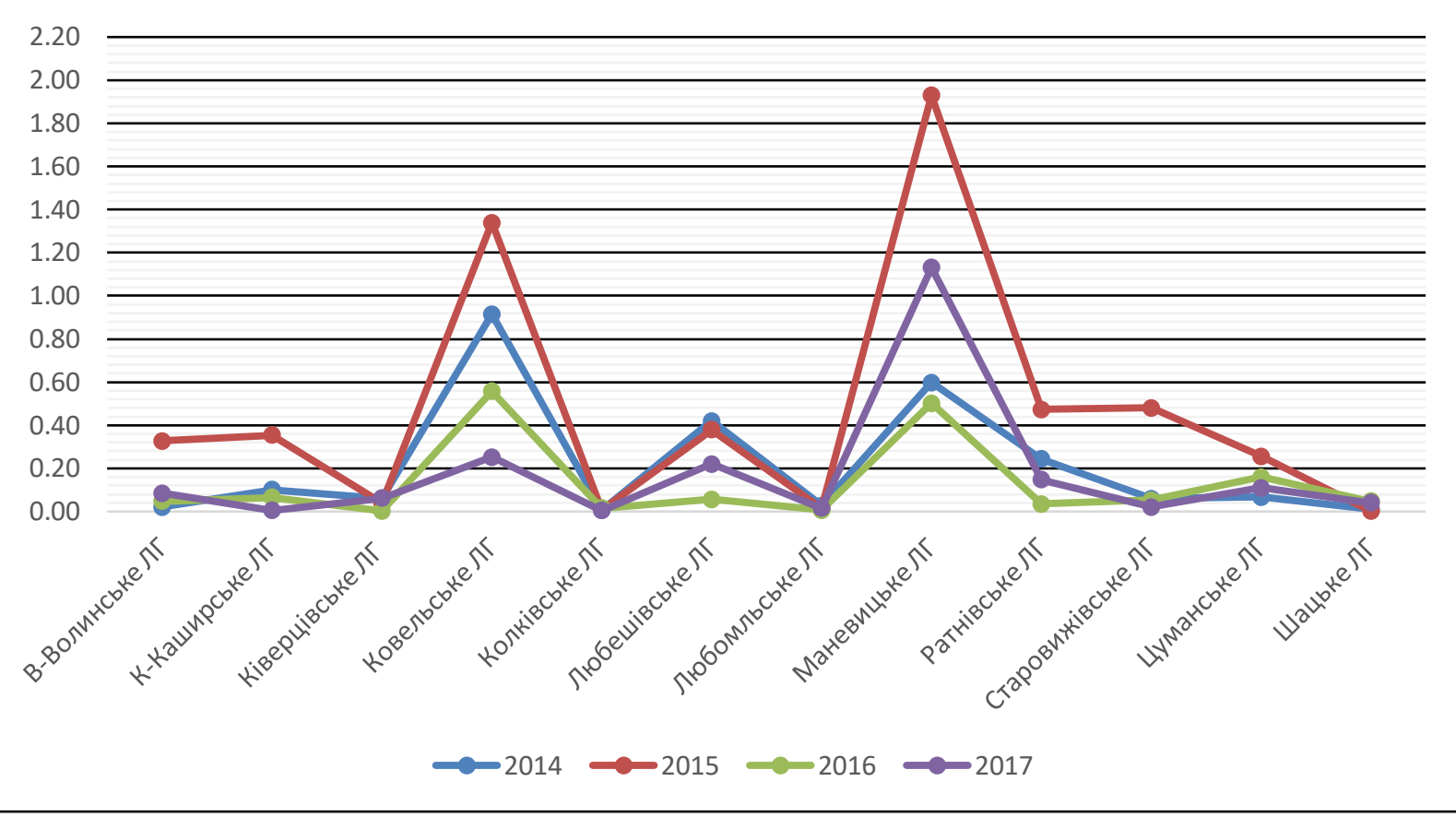

Рис. 3. Коефіцієнт абсолютної ліквідності лісогосподарських підприємств Волинського ОУЛМГ

Джерело: власні розрахунки

В 2014 році показник абсолютної ліквідності відповідав нормативному показнику тільки на чотирьох підприємствах. В 2015 році ситуація змінилась в сторону збільшення підприємств, які змогли б моментально погасити свої борги. Таких підприємств стало вісім із дванадцяти.

В 2016 році ситуація знову кардинально змінилась. Достатній коефіцієнт абсолютної ліквідності мали лише два підприємства; Ковельське ЛГ та Маневицьке ЛГ.

В 2017 році лише Маневицьке ЛГ мало достатньо грошових коштів, щоб негайно погасити свої зобов'язання. Але при цьому існує ще один важливий нюанс: ДП Маневицьке ЛГ має досить високий рівень коефіцієнта абсолютної ліквідності, що може свідчити про не зовсім ефективне використання грошових коштів підприємства.

Переходимо до аналізу фінансової стійкості підприємств Волинського ОУЛМГ.

Фінансова стійкість підприємства є важливою характеристикою фінансового стану підприємства. Вона пов'язана зі ступенем залежності від кредиторів і інвесторів i характеризується співвідношенням власних і залучених коштів.

Першим показником фінансової стійкості підприємства, який обираємо для аналізу $\epsilon$ коефіцієнт концентрації власного капіталу $\left(K_{\kappa в к)}\right.$. Цей коефіцієнт характеризує частку власників підприємства в загальній сумі коштів, авансованих у його діяльність. Чим вище значення цього показника, тим більш фінансово стабільне підприємство і незалежне від зовнішніх кредиторів. Нормативне значення коефіцієнта концентрації власного капіталу більше 0,6 .

$$
\mathrm{K}_{\phi c}=\frac{\phi \cdot 1 \mathrm{p} \cdot 1495}{\phi \cdot 1 \mathrm{p} \cdot 1900}
$$




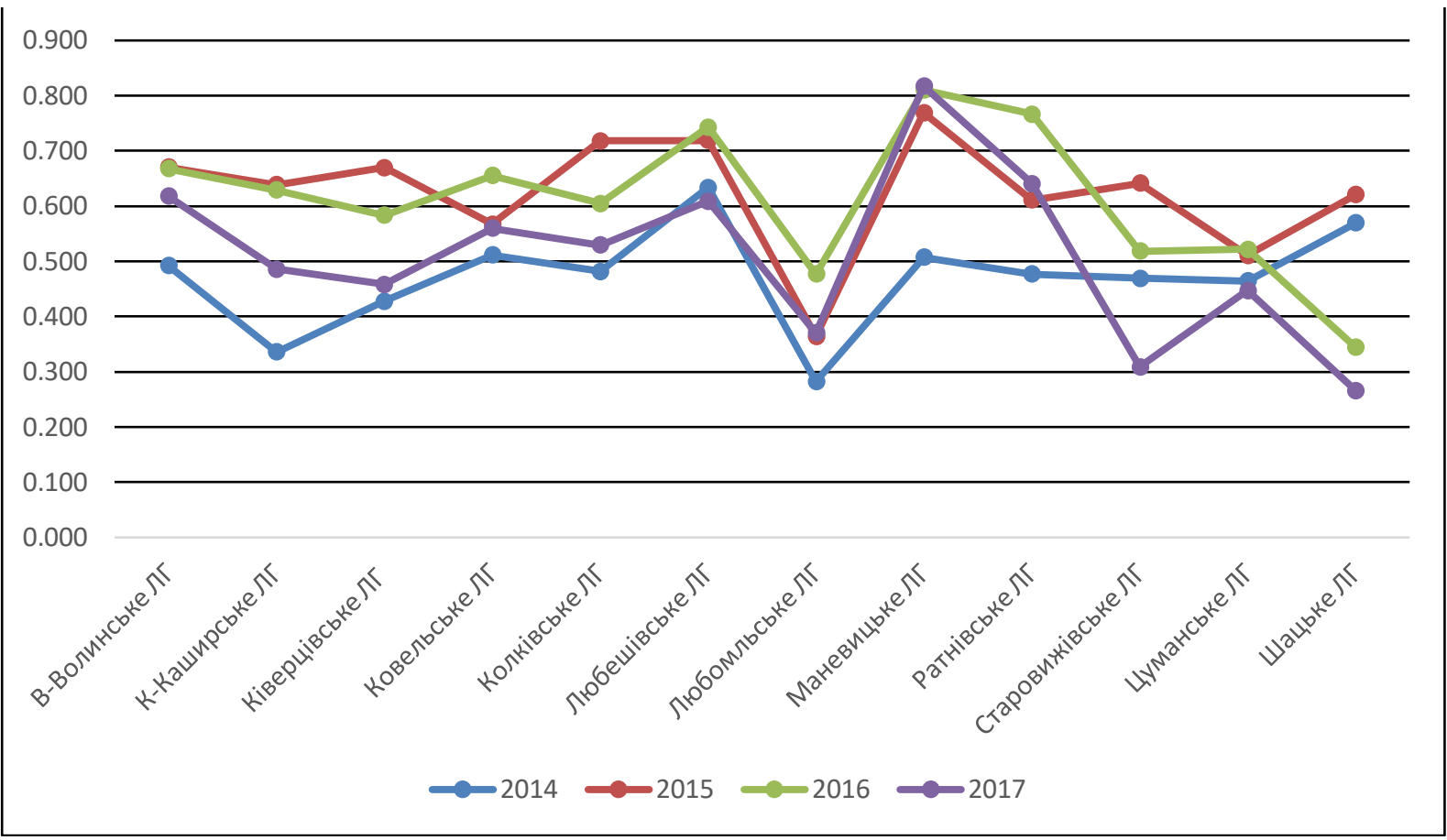

Рис. 4. Коефіцієнт концентрації власного капіталу лісогосподарських підприємств Волинського ОУЛМГ

Джерело: власні розрахунки

3 рис. 4 бачимо, що в 2014 році на підприємствах лісогосподарського комплексу Волинської обл. коефіцієнт концентрації власного капіталу був досить низьким відносно нормативного показника. Найгіршим цей показник був ДП «Любомльське лісове господарство» і становив 0,28. Варто зразу ж зазначити, що назване підприємство і в наступні три роки теж мало досить низький рівень коефіцієнта концентрації власного капіталу. Найбільш фінансово стабільним у 2014 році було ДП «Любешівське ЛГ», коефіцієнт якого перевищив нормативне значення і становив 0,61. В 2014 році це було єдине підприємство, яке перейшло поріг нормативного значення.

За три наступні роки фінансовий стан всіх досліджуваних підприємств змінювався по різному. Найгірший фінансовий стан в 2017 році мало ДП «Шацьке ЛГ», в якого коефіцієнт концентрації власного капіталу становив 0,27 ( для порівняння в 2014 р. 0,56, в 2015p. - 0,62, в 2016p. - 0,34). Найвищі показники коефіцієнта концентрації власного капіталу та можливість погасити борги за рахунок власних коштів в 2017 році мали 3 підприємства: ДП «Маневицьке ЛГ» - 0,82 (в 2016р. - 0,81); ДП «Ратнівське ЛГ» - 0,64 (в 2016p. - 0,77) та ДП «Любешівське ЛГ» - 0,61 (в 2016р. - 0,74).

Наступним показником для аналізу є коефіцієнт фінансової залежності $K_{\Phi 3}$.

$$
\kappa_{\phi 3}=\frac{\phi \cdot 1 \mathrm{p} \cdot 1900}{\phi \cdot 1 \mathrm{p} \cdot 1495}
$$

Цей коефіцієнт є оберненим до коефіцієнта концентрації власного капіталу. Зростання цього показника в динаміці означає збільшення частки позичених коштів у фінансуванні підприємства.

Розглянемо динаміку коефіцієнта фінансової залежності лісогосподарських підприємств Волинського ОУЛМГ (рис.5). 


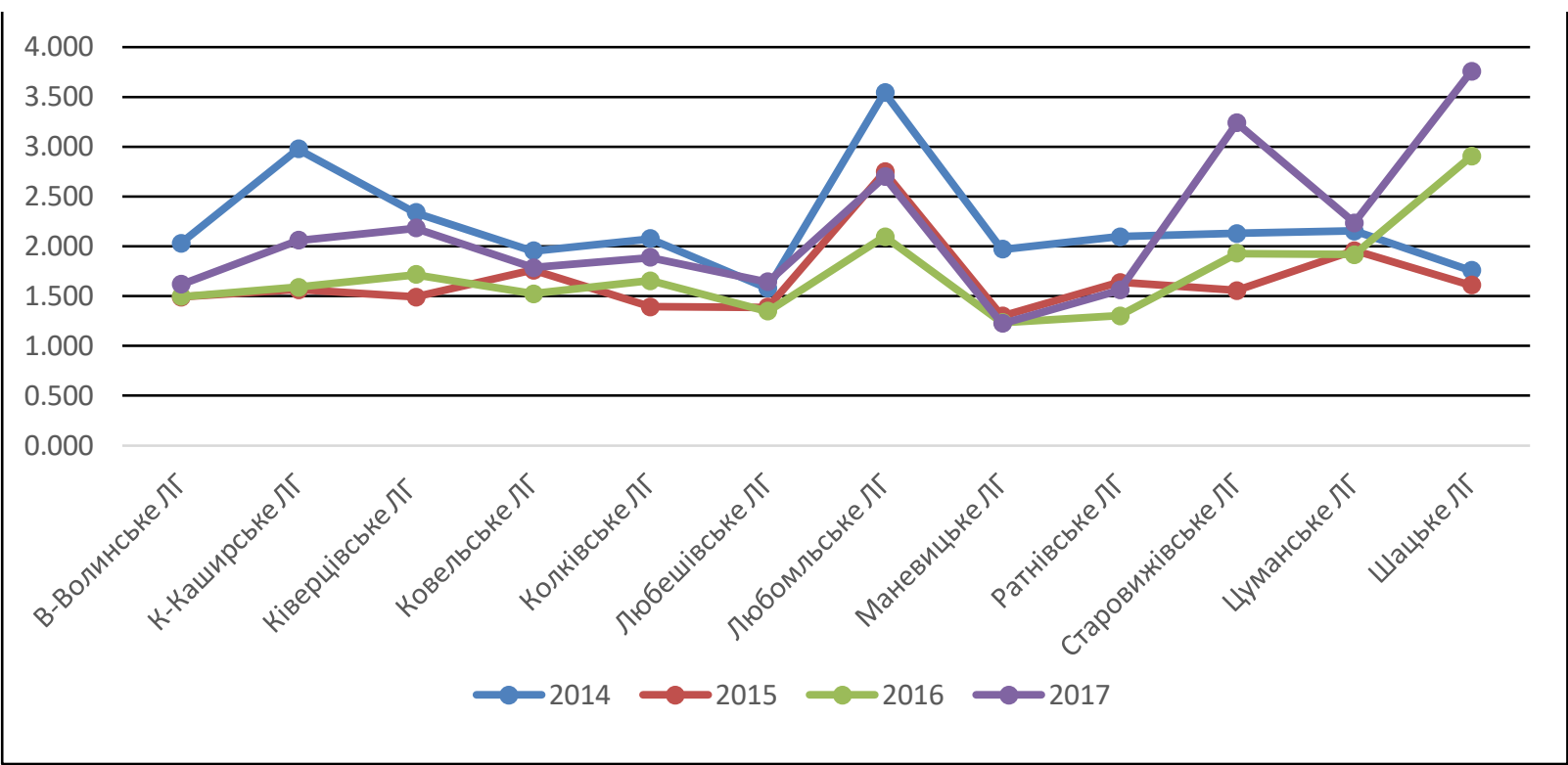

Рис. 5. Коефіцієнт фінансової залежності лісогосподарських підприємств Волинського ОУЛМГ

Джерело: власні розрахунки

Розрахункові дані коефіцієнта фінансової залежності за 2014 рік найвищі за досліджуваний період майже по всіх підприємствах лісового господарства. Це означає, що в 2014 р. значна частка коштів у фінансування підприємств була позиченою. Найбільше значення показника 3,54 було в ДП «Любомльське ЛГ», а це означає, що 3 3,54 грн., вкладених в активи підприємства 2,54 грн. були позиченими. Найменше запозичених коштів використовувалось ДП «Любешівське ЛГ», в якого коефіцієнт фінансової залежності становив 1,57.

В 2016 році фінансовий стан підприємств значно покращився і фінансова залежність від зовнішніх кредиторів значно зменшилась. Найнижчий показник коефіцієнта фінансової залежності мало ДП «Маневицьке ЛГ» 1,23, це означає, що в активи підприємства вкладено 1 грн. власну і лише 0,23 грн. позикові. В цьому році лише одне підприємство ДП «Шацьке ЛГ» майже в два рази в порівнянні 32014 роком збільшило значення коефіцієнта фінансової залежності з 1,75 до 2,90.

В 2017 році фінансова залежність підприємств значно зросла. Найнижчим показник залишився у ДП «Маневицьке ЛГ» - 1,22. Відразу три підприємства значно збільшили свою фінансову залежність в порівнянні з попередніми роками: ДП «Старовижівське ЛГ» - 3,24; ДП «Цуманське ЛГ» - 2,24; ДП «Шацьке ЛГ» - 3,76.

Висновки. Отже, наявність достовірної і оперативної інформації про фінансовий стан лісогосподарських підприємств дає змогу керівникам підприємств вчасно приймати більш виважені рішення щодо підтримки виробництва лісогосподарської продукції, а органам державного управління забезпечує процес регулювання i контролю за економічною діяльність лісогосподарських підприємств.

\section{Список використаних джерел:}

1.Волинське обласне управління лісового та мисливського господарства. Основні показники діяльності у динаміці за 2014-2016 роки. /[Електронний ресурс]. — Режим доступу: http://lis.volyn.ua

2.Волинське обласне управління лісового та мисливського господарства. Фінансова звітність. /[Електронний ресурс]. - Режим доступу: http://lis.volyn.ua

3.Голячук Н.В. Інформаційне забезпечення управління підприємствами лісогосподарського комплексу. - дис. на здобуття наук. ступеня канд. екон. наук за спец. 08.06.01 - «Економіка, організація і управління підприємствами» / Н.В. Голячук. - К., 2004. - 193 с.

Рецензент д.е.н., професор Голян В.А. 